\title{
REFERENCES
}

Anitschkow, N. (1913). Beitr. path. Anat. 56, 379.

Anitschkow, N. (1914). Beitr. path. Anat. 57, 201.

Anitschkow, N. (1933). In Arteriosclerosis. [E. V. Cowdry, editor.] New York: The MacMillan Company.

Bailey, C. H. (I9r6). F. exp. Med. 23, 69.

Barnard, P. J. (1953). J. Path. Bact. 65, r29.

Barnard, P. J. (1954). Circulation, ro, 343.

Cook, R. P. \& McCullagh, G. P. (1939). Quart. F. exp. Physiol. 29, 283.

Duff, G. L. (1936). Arch. Path. 22, 16r.

Duguid, J. B. (1952). Lancet, 263, 207.

Duguid, J. B. (1954). Lancet, 266, $89 \mathrm{I}$.

Duguid, J. B. \& Robertson, W. B. (1955). Lancet, 268, 525.

Foot, N. C. (1925). Anat. Rec. 30, 15.

Graham, D. M., Lyon, T. P., Gofman, J. W., Jones, H. B., Yankley, A., Simonton, J. \& White, S. (195I). Circulation, 4, 666.

Gutmann, N. \& Constantinides, P. (1955). Arch. Path. 59, 717.

Gye, W. E. \& Purdy, W. J. (1924). Brit. F. exp. Path. 5, 238.

Himsworth, H. P. (1938). Acta. med. scand., Suppl. 90, ${ }_{5} 8$.

Hueper, W. C. (194I). Medicine, 20, 397.

Katz, L. M. \& Stamler, J. (1953). Experimental Atherosclerosis. Springfield: C. C. Thomas.

Leary, T. (1941). Arch. Path. 32, 507.

Leary, T. (1949). Arch. Path. 47, I.

Rannie, I. \& Duguid, J. B. (1953). F. Path. Bact. 66, 395.

Wartman, W. B., Hudson, B. \& Jennings, R. B. (195I.). Circulation, 4, 756.

\section{The relationship of lipaemia to thrombosis and atheroma}

\section{By H. W. Fullerton, Department of Medicine, University of Aberdeen}

The important arterial lesion which causes narrowing of the lumen and frequently leads to thrombosis with resultant obliteration is better termed 'atherosclerosis' than 'atheroma'. Duguid (r 949, 1952) has postulated that the pathogenesis of this disorder is fibrin formation or thrombosis, the fibrin or clot becoming covered by the endothelial lining of the intima and incorporated in the vessel wall. His work has been corroborated in important details by Crawford \& Levene (I952), and the evidence in favour of the hypothesis is convincing. Its acceptance entails a fundamental alteration in our conception of atherosclerosis, because the initial abnormalities probably reside in the plasma itself and are not to be sought primarily within the arterial wall.

Some years ago it occurred to us that lipaemia might be a factor responsible for intravascular fibrin formation and the initiation of atherosclerosis. Several considerations suggested this as a possibility. It was known that conditions associated with pathological lipaemia were accompanied by a high incidence of atherosclerosis; in this connexion, diabetes mellitus, the nephrotic syndrome, hypothyroidism and idiopathic hyperlipaemia come readily to mind. Conversely, there was the clinical impression that atherosclerosis was generally slight in the subjects of idiopathic steatorrhoea who would be protected against phases of alimentary lipaemia by impaired absorption of fat (Arnott, 1954). In addition, it had been clearly shown that a lipid factor was necessary for normal blood coagulation (Macfarlane, Trevan \& Attwood, 194I). 


\section{Effect of alimentary lipaemia on clotting time}

With these thoughts in mind we proceeded to determine whether the phase of lipaemia which follows the ingestion of a high-fat meal was associated with an alteration of the clotting time of whole blood. This aspect of the problem was studied in preference to estimations of the clotting times in pathological lipaemia, because the findings during a phase of alimentary lipaemia could be compared with fasting values, and any alterations could be more easily assessed. The technique adopted was briefly as follows (Fullerton, Davie \& Anastasopoulos, 1953). Silicone-coated tubes were used and blood was run into them from a wide-bore needle in a vein at the elbow. The first few ml. of blood were discarded since this sample presumably contained most or all of the thromboplastin arising at the site of venepuncture. Syringes were not used to collect the blood, so that the addition of tissue thromboplastin to the sample was avoided as far as possible. The high-fat meal contained $85 \mathrm{~g}$ fat ( 2 eggs, $2 \frac{1}{2} \mathrm{oz}$. bacon, I-I $\frac{1}{2} \mathrm{oz}$. butter, bread, tea with milk and sugar), and most of the experiments were carried out in normal male volunteers.

Some of our findings are shown in Tables $I$ and 2. In Table $I$ are shown the clotting times in eleven subjects, the observations being made before a high-fat meal and at intervals of $3,3 \frac{1}{2}$ and $4 \mathrm{~h}$ after it. The clotting time was determined in duplicate at each observation, and it is to be noted that the difference between the two readings never exceeded $5 \mathrm{~min}$. In the first nine cases gross macroscopic lipaemia

Table I. Clotting times (min) in normal human subjects before and at various times after a high-fat meal

(Duplicate determinations)

\begin{tabular}{|c|c|c|c|c|c|}
\hline \multirow[b]{2}{*}{$\begin{array}{c}\text { Subject } \\
\text { no. }\end{array}$} & \multirow[b]{2}{*}{$\begin{array}{c}\text { Before } \\
\text { meal }\end{array}$} & \multicolumn{3}{|c|}{ After meal } & \multirow{2}{*}{$\begin{array}{l}\text { Difference } \\
\text { before and } \\
\text { after meal* }\end{array}$} \\
\hline & & $3 \mathrm{~h}$ & $3 \frac{1}{2 h}$ & $4 h$ & \\
\hline I & 25,27 & 20,20 & 20,23 & 15,20 & 9 \\
\hline 2 & 25,25 & I 5, I 5 & I 5, I 5 & 10,10 & I5 \\
\hline 3 & 20,20 & 10,15 & IO, IO & I 4, IO & 10 \\
\hline 4 & 20,25 & 20,20 & 20,15 & $r_{5}, 20$ & 5 \\
\hline 5 & 20,20 & IO, I 3 & 10,10 & $10, I_{5}$ & 10 \\
\hline 6 & 20,20 & $\mathrm{I}_{5, \mathrm{I}} 8$. & 15,12 & 15,12 & 7 \\
\hline 7 & 20,25 & 10,10 & I 5, I 5 & 一 & 12 \\
\hline 8 & 25,20 & 15,20 & 20,20 & 5,10 & I 5 \\
\hline 9 & I 5,20 & 15,10 & IO, I 5 & 15,20 & 5 \\
\hline 10 & 20,20 & 20,25 & 20,20 & 25,20 & 0 \\
\hline II & I 5,15 & I $5, I_{5}$ & 12,10 & 10,14 & 4 \\
\hline
\end{tabular}

* Difference between the mean clotting time before the meal and the lowest mean value after it.

followed the meal, and in each, there was a significant reduction in the clotting time which was usually pronounced. In Subjects Nos. Io and I I macroscopic lipaemia did not develop and the change in clotting time was less than the experimental error of $5 \mathrm{~min}$. 
Table 2 shows similar observations in nine subjects after the ordinary ward breakfast (fat content $12-3 \circ \mathrm{g}$ ). Only in subject no. 9 was there a significant shortening of the clotting time, and this was the only case in which macroscopic lipaemia occurred after the meal.

Table 2. Clotting times (min) in normal human subjects before and at various times after the ordinary ward breakfast

(Duplicate determinations)

\begin{tabular}{|c|c|c|c|c|c|}
\hline \multirow{2}{*}{$\begin{array}{c}\text { Subject } \\
\text { no. }\end{array}$} & \multirow{2}{*}{$\begin{array}{c}\text { Before } \\
\text { meal }\end{array}$} & \multicolumn{3}{|c|}{ After meal } & \multirow{2}{*}{$\begin{array}{l}\text { Difference } \\
\text { before and } \\
\text { after meal* }\end{array}$} \\
\hline & & $3 \mathrm{~h}$ & $3^{\frac{1}{2} h}$ & $4 h$ & \\
\hline I & 15,15 & I 5,20 & I 5, I 5 & I 5 , I 5 & 0 \\
\hline 2 & 15,15 & 15,20 & × 5,15 & I 5, I 5 & 0 \\
\hline 3 & 20,20 & 23,25 & 20,20 & 25,25 & $\circ$ \\
\hline 4 & 30,33 & 25,27 & 25,27 & 25,25 & 6 \\
\hline 5 & 20,20 & 20,18 & 20,20 & 20,22 & I \\
\hline 6 & 25,25 & 22,25 & 25,20 & 25,25 & 3 \\
\hline 7 & 25,25 & 25,25 & 25,25 & 25,25 & 0 \\
\hline 8 & 30,27 & 25,25 & 25,25 & 25,25 & 3 \\
\hline 9 & 20,20 & 10,15 & 10,10 & $10, \times 5$ & ro \\
\hline
\end{tabular}

* Difference between the mean clotting time before the meal and the lowest mean value after it.

From these experiments we drew two conclusions: (I) when macroscopic lipaemia occurs after a meal containing fat it is associated with a considerable increase in the coagulability of blood, and (2) lipaemia of a degree sufficient to produce this effect usually occurs after a meal containing $85 \mathrm{~g}$ fat and seldom when it contains less than $30 \mathrm{~g}$.

\section{Association between dietary fat and coronary atherosclerosis}

It was obvious then that we had to examine what evidence there might be for an association between a high dietary intake of fat and atherosclerosis. We consider that the following observations, taken together, must be regarded as supporting such an association.

(I) First, there is general agreement that the incidence of coronary atherosclerosis, with its clinical presentations of angina pectoris and coronary thrombosis, has been increasing in this country during the past few decades. The precise degree of this increase is impossible to assess because of changing fashions in diagnosis and improving diagnostic facilities. However, the curves for the mortality rate from coronary disease in males have risen since $193 \mathrm{r}$ except for a slight fall which lasted from r940 until r943 (Daw, 1954).

The figures for animal and vegetable fat available for consumption are presented in Table 3. The figures for the period up to 1935 are from Ministry of Health: Advisory Committee on Nutrition (1937). The later figures, which are probably more accurate, are from The Ministry of Food (1953, 1954) bulletins nos. 720 and 755. It is clear that there has been a rise in total fat consumption except for the war years, (when consumption fell to $86 \%$ of prewar levels (Leitner, I954)), and the few years succeeding it. There is, therefore, a rough correlation with the mortality 
Table 3. Fat (g/head/day) available for human consumption in the United Kingdom in various periods before and after the war*

\begin{tabular}{|c|c|c|c|}
\hline & Total & Animal & Vegetable \\
\hline I $909-13$ & 88 & 83 & 5 \\
\hline I924-8 & 98 & 86 & 12 \\
\hline I 934-5 & I 13 & 105 & 8 \\
\hline Prewar & 130 & 107 & 23 \\
\hline 1946 & I I 2 & 80 & 32 \\
\hline 1949 & I2I & $8 \mathrm{I}$ & 40 \\
\hline I954t & 138 & 97 & 41 \\
\hline
\end{tabular}

from coronary disease. On the other hand, the fall in fat consumption during and after the war lasted a few years longer than the fall in mortality from coronary disease. A striking fact is the considerable increase in the consumption of fat from vegetable sources in recent years. Obviously a comparison of the effects of animal and vegetable fats on blood coagulability is urgently required.

In addition to the average figures given above, it is important to realize that the consumption of fat is much greater in the higher-income groups, and it is in them that the incidence of coronary heart disease is greatest.

(2) In Norway during the war dietary fat was reduced to about half the prewar level and, at the same time, there was a marked decrease in the mortality from circulatory diseases (Malmros, 1949; Closs \& Dedichen, 1949).

(3) Keys (1953) has shown that there is a strong correlation between the percentage of the total calories derived from fat and the mortality from degenerative heart disease in different countries with widely differing dietary habits (U.S.A., Canada, Australia, England and Wales, Italy and Japan).

(4) There is a large volume of evidence to show that in atherosclerosis in man the serum-cholesterol level is usually higher than normal. Recent work has shown that this may be taken to indicate simply that in the subjects of atherosclerosis the dietary intake of fat is high (Keys, Mickelsen, Miller \& Chapman, I950), although a derangement of fat metabolism is an alternative explanation.

\section{The role of other factors in the production of atherosclerosis}

Although the conception outlined above may account to a large extent for the increase in coronary atherosclerosis and its varying incidence in different countries and in different social groups, it is obvious that several other factors must be considered.

(I) There is considerable individual variation in the degree of lipaemia which follows a given intake of fat, but repeated observations in any one subject give fairly constant results (Moreton, 1950). It seems probable that constitutional factors are 
important in this respect, as indeed they are known to be in regard to the development of coronary atherosclerosis itself (Gertler \& White, 1954).

(2) The striking preponderance of coronary atherosclerosis in males is probably to be explained by an effect of sex hormones on the distribution of lipoproteins in the blood (Oliver \& Boyd, I953). An extension of the work already done in this field is likely to be rewarding.

(3) The incidence of coronary atherosclerosis is less in subjects with occupations entailing considerable physical exertion than in those with sedentary occupations, irrespective of the social group (Morris, Heady, Raffle, Roberts \& Parks, I953). The possibility that physical activity may modify the degree of lipaemia following fat ingestion is important, and a study of this problem is planned. Moreover, an increase in the mechanization of industry and in all forms of transport has been marked in the past few decades at the same time as fat ingestion has increased, and it is possible that both factors may have played important and complementary parts in the increased incidence of coronary atherosclerosis.

Further study may reveal the importance of other factors. At present all that can be said is that the incidence of coronary atherosclerosis shows some correlation with the fat intake, and although various changes have occurred in our mode of life during the period when coronary atherosclerosis has increased, a high fat intake is the only one of these changes that has been shown to increase directly the coagulability of blood.

\section{The localization of atherosclerotic lesions}

In conclusion, I should like to draw attention briefly to the admirable manner in which the conception of intimal fibrin deposition or thrombosis as the starting point of atherosclerosis accords with the anatomical distribution of the lesions. The incidence of atherosclerosis is highest in the coronary arteries and it is higher in the left coronary artery than in the right. During ventricular systole the flow in the left coronary artery is arrested since the force exerted on the branches of the vessel by the heart muscle is greater than the aortic pressure. In the right coronary artery blood flow is less reduced since the force exerted by the right ventricle is less. Obviously cessation or reduction of blood flow will allow deposition of preformed fibrin on the arterial intima, and this may initiate the process of atherosclerosis. Fibrin deposition would be expected to occur less readily in other arteries although favourable conditions may occur at the origins of branches, where, in fact, the lesions of atherosclerosis are often prominent.

\section{SUMMARY}

I. The evidence for an association between dietary fat and the incidence of coronary atherosclerosis is reviewed.

2. Alimentary lipaemia accelerates the coagulation of blood in vitro, and may initiate the process of atherosclerosis by producing fibrin formation in vivo.

3. The role of other factors, which may be important in the pathogenesis of atherosclerosis, is considered briefly. 


\section{REFERENCES}

Arnott, W. M. (1954). Brit. med. F. ii, 887.

Closs, K. \& Dedichen, J. (r949). Lancet, 257, r 242.

Crawford, T. \& Levene, C. I. (1952). F. Path. Bact. 64, 523.

Daw, R. H. (1954). Lancet, 266, 1079.

Duguid, J. B. (1949). Lancet, 257, 925 .

Duguid, J. B. (1952). Lancet, 263, 207.

Fullerton, H. W., Davie, W. J. A. \& Anastasopoulos, G. (1953). Brit. med. F. ii, 250.

Gertler, M. M. \& White, P. D. (I954). Coronary Heart Disease in Young Adults, p. $3^{6}$. Cambridge, Mass.: Harvard University Press.

Keys, A. (1953). 7. Mt Sinai Hosp. 20, I34.

Keys, A., Mickelsen, O., Miller, E. V. O. \& Chapman, C. B. (1950). Science, rr2, 79.

Leitner, Z. A. (1954). Lancet, 266, 1078.

Macfarlane, R. G., Trevan, J. W. \& Attwood, A. M. P. (1941). F. Physiol. 99, 7P.

Malmros, H. (1949). Nord. med. 42, 1785.

Ministry of Food (1953). Bull. Minist. Fd, Lond., no. 720.

Ministry of Food (1954). Bull. Minist. Fd, Lond., no. 755.

Ministry of Health: Advisory Committee on Nutrition (1937). First Report. London: H.M. Stationery Office.

Moreton, J. R. (1950). F. Lab. clin. Med. 35, 373.

Morris, J. N., Heady, J. A., Raffle, P. A. B., Roberts, C. G. \& Parks, J. W. (1953). Lancet, $265,1053$. Oliver, M. F. \& Boyd, G. S. (1953). Brit. Heart I. 15, $3^{87}$. 